\title{
Overcoming Anxiety During The Covid-19 Using Five-Finger Hypnotic Therapy
}

\author{
${ }^{1}$ Jek Amidos Pardede, ${ }^{2}$ Galvani Volta Simanjuntak \\ ${ }^{1}$ Mental Health Nursing, Sari Mutiara Indonesia University, Medan, North Sumatra, Indonesia \\ ${ }^{2}$ Medical Surgical Nursing, Sari Mutiara Indonesia University, Medan, North Sumatra, Indonesia \\ jekpardedemi@rocketmail.com
}

\begin{abstract}
:
COVID-19 is a infectious disease caused by coronavirus 2 Acute respiratory syndrome (Severe acute respiratory syndrome coronavirus 2 or SARS-CoV-2). This Virus can be transmitted from human to human and has spread widely and raises anxiety in all people. People's anxiety toward Covid-19 should be promptly addressed if unresolved will be poorly engaged. Anxiety towards Covid-19 is higher than the person in general who can lower the quality of life. Anxiety handlers use five-finger hypnotic therapy. Because of the five-finger hypnotic therapy is a process that uses the power of mind by directing the body to heal self-nourishes health/relaxation through communication in the body involving all visual senses, touch, guidelines, vision and hearing. The study aims to determine the effect of fivefinger hypnotic therapy on anxiety levels in people with Covid-19 mentoring (ODP) at Sari Mutiara Hospital. Research design of Quasy exkperiment one group pre-post test. The number of samples used as many as 31 people were selected with the purposive sampling technique. The results showed that the level of anxiety before the fivefinger hypnotic therapy was largely in the medium category of 15 people (48.4\%) At a severe anxiety level as much as 14 people (45.2\%) And at a mild anxiety level as much as 2 people (6.5\%). After the five-finger hypnotic therapy showed that there was a decrease in the number of severe anxiety levels of 2 people $(6.5 \%)$ Mild anxiety Level 11 people $(35.5 \%)$ The anxiety level was 18 people $(58.1 \%)$. The results of this study at Wilcoxon's statistical test were to get the result of $\mathrm{Z}=-3,162$ and $\mathrm{P}$-value of $0.002(\mathrm{P}<0.05)$, there was a significant effect of five-finger hypnotic therapy on the anxiety level of people with Covid-19 (ODP) mentoring.
\end{abstract}

\section{What will audience learn from your presentation?}

$>$ I will immediately practice how to use five-finger hypnotic therapy. So everyone will see me doing five fingers hypnotic therapy..

$>$ I will give you tricks and ways of how to handle anxiety with a caring touch.

$>$ I will give an example in conducting an examination of patients who experience anxiety especially in the present condition with Covid-19.

\section{Biography of presenting author}

Jek Amidos Pardede studied Mental Health Nursing Specialist at University of Indonesia, Indonesia and graduated as M.K.ep., Sp.Kep.J in 2014. Joined the Reviewer at the STIKes Kendal, I have completed a graduate of nursing and Ners profession at Sari Mutiara Indonesia University. Now in college take a PHD program at Lincoln University College, Malaysia. 
Nanotechnology Virtual

1033 Sterling Rd, Unit 104

Herndon, VA 20170, USA

\section{Details of presenting author to be mentioned in certificate:}

Name: Jek Amidos Pardede

Affiliation: Sari Mutiara Indonesia University

Country: Indonesia

\section{Other Details:}

Presentation Category: Oral Presentation

Session Name: Psychosocial nursing diagnoses and care at this covid-19

Email: jekpardedemi@ rocketmail.com

Alternative email: jekpardedemi@gmail.com

Contact Number: 081361009005

LinkedIn: Jek Amidos Pardede

Suggestion of speakers to be invited: Galvani Volta Simanjuntak,

\section{Reference}

1. Lee SA. Coronavirus Anxiety Scale: A brief mental health screener for COVID-19 anxiety. Death studies. 2020 Jul 2;(44):393-401.

2. Pardede JA, Simanjuntak GV, Waruwu JF. Penurunan Tingkat Kecemasan Pasien HIV/AIDS melalui Terapi Hipnotis Lima Jari. Coping: Community of Publishing in Nursing.2020;8:85-90.1

3. Roy D, Tripathy S, Kar SK, Sharma N, Verma SK, Kaushal V. Study of knowledge, attitude, anxiety \& perceived healthcare need in Indian population during COVID-19 pandemic. Asian Journal of Psychiatry. 2020 Apr 8:2083.

4. Pardede JA, Marbun AS, Zikri M. Pengetahuan Dan Sikap Dengan Tindakan Perawat Tentang Patient Safety. Jurnal Keperawatan Priority. 2020 Jul 6;3(2):1-2.

5. Salari N, Hosseinian-Far A, Jalali R, Vaisi-Raygani A, Rasoulpoor S, Mohammadi M, Rasoulpoor S, Khaledi-Paveh B. Prevalence of stress, anxiety, depression among the general population during the COVID-19 pandemic: a systematic review and meta-analysis. Globalization and health. 2020 Dec;16(1):1-12.

6. Pardede JA, Tarigan I. The Anxiety Level of Mother Presectio Caesar with Benson's Relaxation Therapy. Jendela Nursing Journal. 2020 Jun 27;4(1):20-8.

7. Mazza MG, De Lorenzo R, Conte C, Poletti S, Vai B, Bollettini I, Melloni EM, Furlan R, Ciceri F, Rovere-Querini P, Benedetti F. Anxiety and depression in COVID-19 survivors: inflammatory and clinical predictors. Brain, behavior, and immunity. 2020 Oct 1;89:594-600.

8. Pardede JA, Simangunsong MM. Family Support With The Level of Preschool Children Anxiety in the Intravenous Installation. Jurnal Keperawatan Jiwa. 2020 Jul 7;8(3):223-34. 
Nanotechnology Virtual

1033 Sterling Rd, Unit 104

Herndon, VA 20170, USA

9. Labrague, L. J., \& De los Santos, J. A. A. (2020). COVID-19 anxiety among front-line nurses: Predictive role of organisational support, personal resilience and support. Journal of nursing management, 28(7), 1653-1661.

10. Gulo RS, Pardede JA. Stres Kerja Dengan Self Care Perawat Di Rumah Sakit Umum Sari Mutiara Medan. Jurnal Keperawatan Jiwa. 2019;2(3).

11. Asmundson GJ, Taylor S. How health anxiety influences responses to viral outbreaks like COVID-19: What all decision-makers, health authorities, and health care professionals need to know. Journal of Anxiety Disorders. 2020 Apr;71:102211.

12. Pardede JA, Keliat BA, Damanik RK, Gulo AR. Optimalization of Coping Nurses to Overcoming Anxiety in the Pandemic of Covid-19 in Era New Normal. Jurnal Peduli Masyarakat. 2020 Jul 25;2(3):105-12.

13. Asmundson GJ, Paluszek MM, Landry CA, Rachor GS, McKay D, Taylor S. Do pre-existing anxietyrelated and mood disorders differentially impact COVID-19 stress responses and coping?. Journal of anxiety disorders. 2020 Aug 1;74:102271.

14. Pardede JA, Hutajulu J, Pasaribu PE. Harga Diri dengan Depresi Pasien Hiv/aids. Jurnal Media Keperawatan: Politeknik Kesehatan Makassar. 2020;11(01).

15. Huang JZ, Han MF, Luo TD, Ren AK, Zhou XP. Mental health survey of 230 medical staff in a tertiary infectious disease hospital for COVID-19. Zhonghua lao dong wei sheng zhi ye bing za zhi= Zhonghua laodong weisheng zhiyebing zazhi= Journal of industrial hygiene and occupational diseases. 2020 Mar 4;35:E001-.

16. Taubman-Ben-Ari O, Chasson M, Abu Sharkia S, Weiss E. Distress and anxiety associated with COVID-19 among Jewish and Arab pregnant women in Israel. Journal of reproductive and infant psychology. 2020 May 26;38(3):340-348.

17. Pappa S, Ntella V, Giannakas T, Giannakoulis VG, Papoutsi E, Katsaounou P. Prevalence of depression, anxiety, and insomnia among healthcare workers during the COVID-19 pandemic: A systematic review and meta-analysis. Brain, behavior, and immunity. 2019 May 8.

18. Pardede JA, Sitepu SF, Saragih M. The Influence of Deep Breath Relaxation Techniques and FiveFinger Hypnotic Therapy on Preoperative Patient Anxiety. Journal of Psychiatry. 2018;3(1):1-8.

19. Jungmann SM, Witthöft M. Health anxiety, cyberchondria, and coping in the current COVID-19 pandemic: Which factors are related to coronavirus anxiety?. Journal of Anxiety Disorders. 2020 May 20:102239.

20. Marbun A, Pardede JA, Perkasa SI. Efektivitas Terapi Hipnotis Lima Jari terhadap Kecemasan Ibu Pre Partum di Klinik Chelsea Husada Tanjung Beringin Kabupaten Serdang Bedagai. Jurnal Keperawatan Priority. 2019 Aug 3;2(2):92-9. 